\title{
A STUDY ON DETERMING THE FINANCIAL POSITION BASED ON FINANCIAL DIAGNOSIS IN COMPANIES LISTED ON THE BUCHAREST STOCK EXCHANGE
}

\author{
Teodor Hada \\ Teodora Maria Avram ${ }^{2}$
}

\begin{abstract}
This study presents aspects related to determining a company's financial position by means of financial diagnosis, in the case of 64 companies listed on the Bucharest Stock Exchange. The aim of this study is to show, in a wide structure, how to determine a company's financial position. The study is divided into four paragraphs and their related subparagraphs. In the first paragraph the objective, the research methodology and the novelty brought by this study are revealed. In the second paragraph various viewpoints of financial diagnosis construct are shown, followed by a third paragraph where the variables needed to determine financial position and the rating criteria are established, and in the last paragraph the aggregate score is determined. The end of the study is reserved to establishing conclusions and proposals.
\end{abstract}

Keywords: financial diagnosis, financial position, scoring method, aggregate score, Bucharest Stock Exchange

JEL Codes: G12, G31, G32, M41

\section{Introduction}

Built on the words of the great French philosopher Claude Adrien Helvetius, "The one who knows the cause is the master of effects", this work aims to an analysis of the financial diagnosis for 64 companies listed on the Bucharest Stock Exchange. The objective of this research is to determine their financial position by applying the "Cematt" metod, based on a case study in the analyzed companies.

The methodology for developing this work involved selecting the topic, documentation, data collection, observation, comparison and financial analysis. The topic selected A Study on Determining the Financial Position based on Financial Diagnosis in Companies Listed on the Bucharest Stock Exchange is based on the idea that knowing the financial diagnosis of a company implies to previously determine its financial position. The reference cited in this study is bibliographic, since there appear different viewpoints of Romanian and foreign authors on the present research, as well as a practical study on the companies listed on the Bucharest Stock Exchange. Another stage in this study consisted in collecting data published in books and works of authors, from studies and articles published in professional journals for the theoretical section, and from the company's financial statements for the practice. After having gathered all the required data, we passed to observation, analysis and comparison of these data. The work cited at the end of the study made possible to present the level of documenting and broadening knowledge on companies' financial diagnosis, based on determining their financial position.

\footnotetext{
1 “1 Decembrie 1918” University, Alba Iulia, România, email: teohada@yahoo.com

2 “1 Decembrie 1918” University, Alba Iulia, România, email: avram_teodora@ymail.com 
The novelty brought by this study consists in the analysis of a large number of companies to determine their financial position using the method "Cematt", which is a method meeting the analysis requirements of the Romanian economy.

\section{General considerations on financial diagnosis}

The term "diagnosis" is a particular method of access to knowledge, which identifies the current situation and prepares determining the project goals (Christian Bottin, 1991, p. 201).

Global diagnosis is "the underlying pattern analyzing the company in a global perspective via its functions and organization and reaching to proposals for its improvement". Global diagnosis includes the following diagnostic categories: financial diagnosis, the diagnosis of the adaptive capacity on the market requirements, technology diagnosis, quality diagnosis, diagnosis of overall management quality, and diagnosis of human resources (Jean-Pierre Thibaut, 1989).

Due to the business environment in which companies operate, they are subject to economic risk, financial risk and bankruptcy risk. Therefore determining the financial risk is a must to highlight the risks that might disrupt the company's future work.

The financial accounting diagnosis "can be reduced to risk assessment assumed by an external partner, as a result of its business relationship with the company and primarily requires assessing the solvency of the company's guarantors" (Silvia Petrescu, 2008, p. 252).

The aims of financial diagnosis are "to measure the company's return on equity, to assess economic and financial risk with which it achieved this profitability and to assess the company's value as a ratio between obtained and assumed return" (Ion Stancu, 2007, p. 755).

Maria Niculescu (2003, p. 22) defines economic financial diagnosis as being "a handy tool allowing managers to formulate qualitative and/or quantitative judgments on a company's status, growth and expectations, emphasizing its strengths and weaknesses, and its capacity to grow in a profitable manner".

The financial diagnosis is "the result of the company's financial potential assessing process and implies different objectives for shareholders, such as financial, economic and commercial return, bankruptcy risk, the autonomy degree and, in the case of creditors, the bankruptcy risk, solvency risk, and liquidity risk" (Mihaela Onofrei, 2006, pp. 43-44).

The current study used diagnosis method lately applied by some Romanian management consulting companies, named "Cematt" (Cezar Mereuta, 1994, p.76), with the necessary improvements to establishing the criteria and scoring of the financial diagnosis.

\section{Analysis of financial position}

The balance sheet structure reveals the "assets, liabilities, and equity, and the relationship between them, namely the financial position. Financial statement analysis is based on the data in the balance sheet and includes: the analysis of economic resources controlled by the company, the analysis of financial structure of assets, liabilities and capital, the company's liquidity and solvency analysis, and financial adjustment” (Maria Bătrâncea, Larissa-Margareta Bătrâncea, 2004, p. 145).

To determine the financial position, a number of 64 companies have been studied, according to the Top 100 market capitalization issuers, listed on Bucharest Stock Exchange. The data were processed using the annual financial statements denominated in lei for 2011, published on the Bucharest Stock Exchange website.

\section{Criteria for determining financial diagnosis using financial ratios}

The company's financial diagnosis, seen as "area and depth is organic, conditioned by the variables framework and informational capacity of each" (Teodor Hada, 2010, p. 312). To determine the financial diagnosis, using the Cematt method, a number of 11 variables were used: 
- Economic Return (Er) "measures the material and financial resources efficiency, assigned to the company's entire activity. The capitals on which business profitability will be analyzing are those engaged by the company in the exercise, to increase the owners' assets, and pay the capital providers" (Nicoleta Bărbuţă-Mişu, 2009, p. 95).

$$
\mathrm{Er}=\frac{\text { Operation result }}{\text { Total assets }} \times 100
$$

- Financial Return (Fr) "remunerates the reserve owners of the company, which in fact, represents an increase of owners' assets, by their incorporation into capital, and hence an increase in the shares taken" (Georgeta Vintilă, 2004, p. 196).

$$
\text { Fr }=\frac{\text { Net result }}{\text { Equity }} \times 100
$$

- $\quad$ Productivity of invested capital (Pic) is determined by reporting net turnover, present in the profit and loss of assets in the balance sheet.

$$
\text { Pic }=\frac{\text { Net turnover }}{\text { Non current assets }}
$$

- Indebtedness rates (Ir) computed "as the proportion where the total assets is financed from sources other than its own, such as loans, suppliers, debts to the state" (Ion Stancu, 2007, p. 777).

$$
\mathrm{Ir}=\frac{\text { Debts: The amounts to be paid within a period of more than one year }}{\text { (Debts: The amounts to be paid within a period of more than one year }+ \text { Equity) }} \times 100
$$

- $\quad$ Financial Leverage ( $\mathrm{Fl})$ is "the ratio between financial liabilities and equity, reflecting the ability of financial managers to attract external resources to stimulate the efficiency of equity" (Ion Stancu, 2007, p.777).

$$
\mathrm{Fl}=\frac{\text { Debts: The amounts to be paid within a period of more than one year }}{\text { Equity }} \times 100
$$

- $\quad$ Correlation between term debt and ability to finance itself (Cbtdafi) starts from the assumption that "if long-and medium-term requirements, under the condition that the debt should not exceed a certain multiple of the cash flow. The higher the self-financing capacity, the more increases the possibility of resorting to loans. Loans under these conditions is a positive factor for the company, interest being covered by the return obtained, the company still having a profit which could be used for paying input, tax due, etc.” (Teodor Hada, 1999, p. 177).

$$
\text { Cbtdafi }=\frac{\text { Term debts }}{\text { Ability to finance itself }}
$$

where: Term debt = Debts: The amounts to be paid within a period of more than one year

- $\quad$ Liquidity asset $(\mathrm{La})$ reflects "the ability of current assets available to turn into cash, to cover the company’s liabilities” (Maria Bătrâncea, Larissa-Margareta Bătrâncea, 2004, p. 172).

$$
\mathrm{La}=\frac{\text { Current assets }+ \text { Prepaid expenses }}{\text { Current liabilities }}
$$


where: Current liabilities $=$ Debts: The amounts to be paid within a period of less than one year Revenue in advance

- $\quad$ Rotational speed of current assets (Rsca), according to Teodor Hada (1999, p. 124) it comes from the fact that "in order to follow the rotation of current assets, during a rotation, the financial practices has created rotation of current assets variable in days, variable which measures the efficient use of working capital".

$$
\text { Rsca }=\frac{\text { (Current assets }+ \text { Prepaid expenses) }}{\text { Net turnover }} \times \mathrm{T}
$$

where: " $\mathrm{T}$ " is time and is equal to 365 days

- $\quad$ Reduced liquidity (R1), according to professors Monica Violeta Achim and Sorin Nicolae Borlea (2012, p. 232) it emphasizes "the ability of current assets with high and average liquidity to face the entity's current liabilities".

$$
\mathrm{Rl}=\frac{\text { (Current assets }+ \text { Prepaid expenses) }- \text { Inventories }}{\text { Current liabilities }}
$$

- $\quad$ Patrimonial solvency (Ps) is "the ability of the company to meet short-term maturities. It results from the balance between revenue and expenditure flows. Capital adequacy ratio is measured by ratios taking into account the liquidity of its assets and the liability of its debts. Patrimonial solvency relates its equity to total liabilities" (Marin Toma, Marius Chivulescu, 1994, p. 71).

$$
\text { Ps }=\frac{\text { Equity }}{\text { Total liabilities }} \times 100
$$

- $\quad$ Immediate liquidity (Il) measure "the degree to which money availabilities covers maturing payments” (Maria Bătrâncea, Larissa-Margareta Bătrâncea, 2004, p. 174).

$$
\text { Il }=\frac{\text { Cash and banks }}{\text { Debts : The amounts to be paid within a period of less than one year }}
$$

Next we determined the variables needed for financial diagnosis for 2011 using the formulas outlined above, and the values of these variables are presented in Annex no. 1 "Determining financial variables needed for financial diagnosis (1)" and Annex no. 2 "Determining financial variables needed for financial diagnosis (2)". The computation of variables required to determine the financial position was performed using balance sheets and profit and loss accounts in lei, for companies subject to the current study. For example, the economic return of the company COS Târgovişte (COS) was determined as follows: $(-117.182 .073 / 499.900 .018) \times 100=-23,44 \%$, the financial return o OMV Petrom S.A. (SNP), the result of Annex no. 1 was thus obtained: $(3.685 .607 .226 / 18.890 .892 .162) \times 100=19,51 \%$. Other variables is invested capital productivity for Casa de Bucovina-Mountain Club (BCM) the result obtained was thus determined: 5.379.360 / $27.520 .502=0,20$; the indebtedness rates for Electromagnetica S.A. București (ELMA) is $(1.558 .086 /(1.558 .086+269.148 .045)) \times 100=0,58 \%$; the financial leverage was thus determined for Teraplast S.A. (TRP): $(35.999 .810 / 130.073 .871) \times 100=27,68 \%$. The correlation between term debt and ability to finance itself for Prodplast S.A. (PPL) was calculated as follows: 0 / 3.753.950 $=0$. The liquidity asset in the case of Amonil S.A. (AMO) is: $32.751 .343 / 19.772 .384=$ 1,66; the variable rotational speed of current assets for Mefin S.A. (MEF) was thus determined: $(24.991 .134 / 994.713) \times 365=9.170,25$ days; the reduced liquidity for OIL Terminal S.A. (OIL) was computed taking into account: $(16.477 .888-2.876 .496) / 26.578 .205=0,51$; the patrimonial 
solvency in the case of Socep S.A. (SOCP) is: $(99.800 .086 / 106.795 .772) \times 100=93,45 \%$; and the immediate liquidity for Ves S.A. (VESY) includes: $1.157 .131 / 24.580 .567=0,05$. Therefore, based on the pattern for each variable, on a company analyzed in this study, the same was done for each of the 64 companies listed on the Bucharest Stock Exchange.

\section{Scoring using the score framework}

In order to sustain the options for restructuring solutions and strategic plans to guide a company in the current period of transition to a market economy, the "Cematt" analyzing pattern is designed as a multicriteria diagnostic tool of the company's status.

The structure of the pattern is heuristic because it refers to a procedure of searching for an unknown target, using several criteria to obtain a complete picture of the company's status. The procedure involves evaluation and successive aggregation of assessments (Teodor Hada, 1999, p. 218).

The assessment mechanism follows the principle that for each criterion " $\mathrm{i}$ " in " $\mathrm{Dj}$ " is set a number of points "Nij" where $\mathrm{i}=\mathrm{n}$ and $\mathrm{j}=1,6$ with the property that "Nij" belongs to the set $\mathrm{N}=$ $\{20,40,60,80,100\}$. The minimum of the set, i.e. 20 is the score given to a criterion which is a situation of total or almost total lack of adaptation to the requirements of a market economy; the maximum element of the set "N", i.e. 100 shows a situation of meeting a high-level international requirements ( $5^{\text {th }}$ International Vilnius Conference, 2009, p. 252).

- $\quad[0,20]$ - concealed bankruptcy - detection of profit centers and starting the procedures for the sale of the company;

- $\quad[21,40]$ - critical situation - radical restructuring, taking measures to overcome the "alarm thresholds" significant restriction of activity, significant changes of profile / markets, capital inflows;

- $[41,60]$ - difficult balance - major restructuring, new targets in the short / medium term, commercial marketing activities, improvement of management and drastic schemes of savings, capital inflow;

- $\quad[61,80]$ - satisfactory adjustment - selection of strategic objectives, "freezing" unprofitable business, capital inflow;

- $\quad[81,100]$ - validity in competitive environment - adopting a corporate offensive strategy, in this case major restructurings are not required.

The scoring for the criteria shown below, presents the score for each criterion 20, 40, 60, 80, 100 according to the limits set for the value of the criterion $\left(5^{\text {th }}\right.$ International Vilnius Conference, 2009, p. 248)

\begin{tabular}{|c|c|c|c|c|c|}
\hline & 20 & 40 & 60 & 80 & 100 \\
\hline Economic profitability (should fall below $10 \%$ ) & $<4$ & $(4,10]$ & $(10,15]$ & $(15,20]$ & $>20$ \\
\hline Return on equity (will not fall below $5 \%$ ) & $<2$ & $(2,5]$ & $(5,10]$ & $(10,15]$ & $>15$ \\
\hline The productivity of $i$ & $<2$ & $(2,3]$ & $(3,4]$ & $(4,5]$ & \\
\hline Indebtedness rate ( $\mathrm{u}$ & $>0,80$ & $(0,60-0,80]$ & $(0,40-0,60]$ & $(0,20-0,40]$ & $<0,20$ \\
\hline Fin & $>175$ & $(175-150]$ & $(150-125]$ & $(125-100]$ & $<100$ \\
\hline $\begin{array}{l}\text { Corr } \\
\text { of se }\end{array}$ & $>10$ & $(10-8]$ & $(8-6]$ & $(6-4]$ & $<4$ \\
\hline I not fall below 1.30 ) & $<1,30$ & $(1,30-1,40]$ & $(1,40-1,50]$ & $(1,50-1,60]$ & $>1,60$ \\
\hline & $>120$ & $(90-$ & $(60-90]$ & $(30-60]$ & \\
\hline $\operatorname{Re}$ & $<1$ & $(1-1,20]$ & $(1,2-1,40]$ & $(1,40-1,60]$ & $>1$, \\
\hline Patr & $<25$ & $(25-50]$ & $(50,75]$ & $(75-100]$ & $>10$ \\
\hline Immediate liquidity & $<0,25$ & $(0,25-0,50$ & $(0,50-0,75$ & ] $(0,75-1]$ & \\
\hline
\end{tabular}


With the 11 variables, determined in the previous paragraph, the score was established for them, according to Annex no. 3 "Setting the scoring and determining the aggregate mark" using the score method. For example, for economic profitability, in the case of the company Alumil Rom Industry SA (ALU ), the rate is 4,59\% and gained 40 points since it falls between 4 and 10 . Therefore bounding the values outlined above, the equity for Dafora S.A. (DAFR) has a value of $1,27 \%$ and a score of 20 , the productivity of invested capital has the value of 2,75 for Zentiva SA (SCD) and 40 points, the indebtedness rate for Electroargeş SA Curtea de Arges is worth 0\% and has a score of 100, in the case of the company S.N.T.G.N. TRANSGAZ S. A. (TGN), the financial leverage has the value of 2,30\% and a score of 100. Other indicators used are the correlation between term debt and ability to finance itself; in the case of Socep SA (SOPC) it has a value of 0,18 and 100 points. As concerns the liquidity asset a value of 1,23 and a score of 20 belongs to the company Artego SA Târgu Jiu (ARTE), the rotation speed of current assets COMELF S.A. (CMF) is $2.719,83$ days and 20 points, in the case of Retrasib S.A. Sibiu (RTRA), low liquidity has a value of 0,69 and a score of 20 , the solvency asset has a value of $75.23 \%$ and a score of 80 , these values being recorded by Calipso S.A. Oradea (CAOR), and for immediate liquidity the company Boromir Prod S.A. Buzau - Spicul (SPCU) has recorded the value of 0,31 and 40 points.

According to the analysis above, the company that is closest to the score limit allowed is the CONTED SA Dorohoi company (CNTE), thereby obtaining the status of viable in its competitive environment, and the one that is the farthest from the maximum score are the companies Cemacon S.A. Cluj-Napoca (CEON), Electroputere S.A. (EPT), Petrolexportimport S.A. (PEI), these companies obtaining therefore the concealed bankruptcy grade.

\section{Determining the aggregate score}

For each criterion " $i$ " in " $\mathrm{Dj}$ " a degree of importance is set, which corresponds to a coefficient of importance "Kij”" so (Teodor Hada, 1999, pp. 218-219):

- $\quad \mathrm{Kij}=5$ for a very important criterion (the consequences of its failure are extremely serious in the entire fulfillment);

- $\quad \mathrm{Kij}=2$ for a major criterion (the consequences of its failure are serious, but only at the level of departments or sections);

- $\quad \mathrm{Kij}=1$ for a secondary criterion (the consequences of its failure has isolated effects).

The importance for each variable is set forth in Annex no. 3 "Setting the scoring and determining the aggregate score".

For each diagnosis direction reviewed " $\mathrm{Dj}$ " the aggregate score is calculated using:

$$
\mathrm{N}_{\mathrm{Dj}}=\frac{\sum_{\mathrm{i}=\mathrm{i}}^{\mathrm{n}_{\mathrm{j}}} K_{\mathrm{ij}} \times N_{\mathrm{ij}}}{\sum_{\mathrm{i}=1}^{\mathrm{n}_{\mathrm{j}}} K_{\mathrm{ij}}}
$$

The aggregate score is a weighted average of the scores assigned to each criterion of diagnosis direction "Dj", having as weighting coefficients, the importance of criteria coefficients in the direction "Dj" (Teodor Hada, 2010, p. 219).

The last column of Annex no. 3 "Setting the scoring and determining the aggregate score" shows the results of calculating the aggregate score. Taking as an example the company Armatura SA (ARM), the aggregate score was determined as follows:

$$
\mathrm{N}_{\mathrm{D} 1}=\frac{(20 \times 2)+(20 \times 5)+(20 \times 1)+(20 \times 5)+(20 \times 2)+(100 \times 5)+(100 \times 1)+(100 \times 1)+(20 \times 5)+(20 \times 1)+(20 \times 5)}{2+5+1+5+2+5+1+1+5+1+5}=36,97
$$


Another example is the company Synthesis S.A. (STZ) where the aggregate score is equal to:

$$
\mathrm{N}_{\mathrm{D} 2}=\frac{(20 \times 2)+(20 \times 5)+(20 \times 1)+(20 \times 5)+(100 \times 2)+(100 \times 5)+(20 \times 1)+(100 \times 1)+(20 \times 5)+(80 \times 1)+(20 \times 5)}{2+5+1+5+2+5+1+1+5+1+5}=41,21
$$

points

The highest value of the aggregate score is held by Alumil Rom Industry S.A. (ALU) with a total score of 383,03 points, so it surpasses 100 the highest value in terms of classification, therefore this company works properly. The lowest score of 24,24 points is owned by the company Dafora S.A. (DAFR), the value falling under the classifications synthesis in a critical situation, and at first glance, most companies reviewed rated as difficult balance.

\section{Conclusions}

By the study conducted, with the help of financial statements and the work cited, I found the need to introduce such methods in the companies to more accurately identify and analyze financial diagnosis.

On this basis, I can conclude that financial diagnosis is part of the global diagnosis, which through a system of variables may show aspects of financial equilibrium, the company's position, its liquidity, the company's performance at a time, and allow making decisions on the future of the company.

Determining the financial position was performed by using 11 variables based on profitability, liquidity, solvency, rotational speed, and the correlation between debts and the capacity of self-financing, these variables being expressed in ratios, days and percentages. After calculating the exposed variables for all 64 analyzed companies, I have moved to the next stage in which each company and each variable was given a score. For example, the company Conted S.A. Dorohoi (CNTE) received 100 points for financial return because it has a value of $22,07 \%$, thus is higher than $15 \%$; another example is the case of Alro S.A. (ALR) which obtained a score of 20 for the rotational speed of current assets, because it has a value of 1.046,02 days and it is greater than 120 days. For immediate liquidity variable the company Prefab S.A. Bucharest (PREH) was awarded 40 points because its value is between 0,25 and 0,50. Once set the scores, we were able to set the coefficients of importance, and in the end the aggregate score was calculated for each company separately.

A proposal for the companies to reduce their financial imbalance would be to try to calculate and constantly check the financial diagnosis situation, by using various methods, including the "Cematt" method, considered one of the most reliable methods to be used in the current period.

According to all those presented, compared, calculated, analyzed, I could rank the analyzed companies, thus leaders being Alumil Rom Industry S.A. (ALU), Conted S.A. Dorohoi (CNTE), Mecanica Ceahlau (MECF). One can afirm that most of the analyzed and listed on the Bucharest Stock trading companies are in the middle area, with unstable balance that must be kept constantly under control to avoid falling into a lower rating, but only to rise, in order to obtain the desired maximal effects.

\section{References:}

1. $5^{\text {th }}$ International Vilnius Conferince, 2009. Knowledge-Based Technologies and OR Methodologies for Strategic Decisions for Sustainable Development, Edited by $\mathrm{M}$. Grassebauer L. Sakalauskas E. K. Zavadskas, pp. 248-252 
2. Achim M. V., Borlea S. N., 2012. Analiza financiară a entităţii economice, Editura Risoprint, Cluj-Napoca, p. 232

3. Bărbuţă-Mişu N., 2009. Finanţele intreprinderii, Editura Didactică şi Pedagogică, Bucureşti, p. 95

4. Bătrâncea L. M., Bătrâncea M., 2004. Analiza financiară a întrepriderii, Editura Risoprint, Cluj Napoca, pp. 145-174

5. Bottin C., 1991. Diagnostic et changement, les Editions d`Organisation, p. 201

6. Chivulescu M., Toma M., 1994. Ghid pentru diagnostic şi evaluare a intreprinderii, Editura CECCAR, București, p. 71

7. Hada T., 1999. Finanţele agenţilor economici din România, Editura Intelcredo, Deva, pp. 124-219

8. Hada T., 2010. Gestiunea financiară a întreprinderii, Ediţia a II-a actualizată şi completată, Editura Aeternitas, Alba Iulia, p. 312

9. Mereuta C., 1994. Analiza diagnostic a societăţilor comerciale în economia de tranziţie, Editura Tehnica, Bucureşti, p. 76.

10. Niculescu M., 2003. Diagnostic global strategic, Volumul 1, Editura Economica, Bucureşti, $\mathrm{p} 22$

11. Onofrei M., 2006. Management financiar, Editura C. H. Beck, Bucureşti, pp. 43-44

12. Petreşcu S., 2008. Analiză şi diagnostic financiar-contabil, Editura CECCAR, Bucureşti, p. 252

13. Site-ul Bursei de Valorii Bucureşti - www.bvb.ro

14. Stancu I., 2007. Finanţe, Ediţia a IV-a, Editura Economică, Bucureşti, pp. 755-777

15. Thibault J. P., 1989. Le diagnostic d'entreprise: guide pratique, Sedifor

16. Vintilă G., 2004. Gestiunea financiară a întreprinderii, Editura Didactică şi Pedagogică, Bucureşti, p. 196 
Annex no. 1

Determining financial variables needed for financial diagnosis (1)

\begin{tabular}{|c|c|c|c|c|c|c|c|c|c|c|c|c|}
\hline \multirow[t]{2}{*}{$\begin{array}{c}\text { Company } \\
\text { name } \\
\text { (transaction } \\
\text { symbol) }\end{array}$} & \multirow[t]{2}{*}{$\begin{array}{l}\text { Operating } \\
\text { result }\end{array}$} & \multirow[t]{2}{*}{$\begin{array}{c}\text { Total assets } \\
\text { or Total } \\
\text { liabilities }\end{array}$} & \multirow[t]{2}{*}{ Net result } & \multirow[t]{2}{*}{ Equity } & \multirow[t]{2}{*}{$\begin{array}{c}\text { Net } \\
\text { turnover }\end{array}$} & \multirow[t]{2}{*}{$\begin{array}{l}\text { Non current } \\
\text { assets }\end{array}$} & \multirow[t]{2}{*}{\begin{tabular}{|c|} 
Debts: The \\
amounts to be \\
paid within a \\
period of more \\
than one year
\end{tabular}} & $\begin{array}{c}\text { Economic } \\
\text { profitabili } \\
\text { ty }\end{array}$ & $\begin{array}{c}\text { Return } \\
\text { on equity }\end{array}$ & \multirow[t]{2}{*}{$\begin{array}{c}\text { The } \\
\text { producti } \\
\text { vity of } \\
\text { invested } \\
\text { capital } \\
\text { coeff. }\end{array}$} & \multicolumn{2}{|r|}{$\begin{array}{c}\text { Financ } \\
\text { ial } \\
\text { Levera } \\
\text { ge }\end{array}$} \\
\hline & & & & & & & & \multicolumn{2}{|c|}{$\%$} & & \multicolumn{2}{|c|}{$\%$} \\
\hline ALR & 368.408 .008 & 2.428 .474 .516 & 228.309 .982 & 1.553 .478 .084 & 2.241 .390 .928 & 1.496 .637 .226 & 572.823 .176 & 15,17 & 14,70 & 1,50 & 26,940 & 36,87 \\
\hline ALT & 4.394 .743 & 176.219 .694 & 378.405 & 108.817 .664 & 133.908 .870 & 117.144 .492 & 2.601 .708 & 2,49 & 0,35 & 1,14 & 2,34 & 2,39 \\
\hline ALU & 3.815 .574 & 83.213 .766 & 3.683 .071 & 67.317 .750 & 74.007 .746 & 21.550 .788 & 0 & 4,59 & 5,47 & 3,43 & 0 & 0 \\
\hline AMO & -23.407 .846 & 89.426 .766 & -22.741 .061 & 65.085 .786 & 9.627 .605 & 56.675 .423 & 0 & $-26,18$ & $-34,94$ & 0,17 & 0 & 0 \\
\hline APC & 8.775 .309 & 80.863 .942 & 7.163 .903 & 61.770 .689 & 90.153 .992 & 26.826 .467 & 0 & 10,85 & 11,60 & 3,36 & 0 & 0 \\
\hline ARM & -1.232 .542 & 28.280 .824 & -2.099 .932 & 174.910 & 20.075 .758 & 14.646 .848 & 21.598 .500 & $-4,36$ & $-1.200,58$ & 1,37 & 99,20 & $12.348,35$ \\
\hline ARS & 14.503 .430 & 160.559 .680 & 11.618 .296 & 102.543 .403 & 158.402 .223 & 75.459 .594 & 0 & 9,03 & 11,33 & 2,10 & 0 & 0 \\
\hline ART & 89.823 .532 & 901.458 .946 & 67.503 .261 & 428.779 .733 & 856.313 .578 & 473.477 .735 & 303.629 .332 & 9,96 & 15,74 & 1,81 & 41,46 & 70,81 \\
\hline ARTE & 8.233 .409 & 151.715 .681 & 4.349 .174 & 78.885 .933 & 198.265 .652 & 61.922 .741 & 33.936 & 5,43 & 5,51 & 3,20 & 0,04 & 0,04 \\
\hline ATB & 32.062 .861 & 449.313 .171 & 20.298 .909 & 287.058 .407 & 281.847 .455 & 175.363 .858 & 0 & 7,14 & 7,07 & 1,61 & 0 & 0 \\
\hline BCM & 136.197 & 41.781 .363 & 792.059 & 41.188 .707 & 5.379 .360 & 27.520 .502 & 0 & 0,33 & 1,92 & 0,20 & 0 & 0 \\
\hline $\mathrm{BIO}$ & 15.707 .018 & 184.918 .511 & 14.220 .788 & 153.957 .996 & 93.443 .090 & 68.660 .609 & 402.687 & 8,49 & 9,24 & 1,36 & 0,26 & 0,26 \\
\hline BRM & 2.521 .139 & 29.320 .729 & 2.255 .143 & 23.061 .192 & 23.098 .100 & 16.036 .533 & 0 & 8,60 & 9,78 & 1,44 & 0 & 0 \\
\hline CAOR & 834.125 & 90.741 .231 & 1.251 .432 & 68.265 .291 & 6.056 .335 & 78.958 .057 & 11.402 .695 & 0,92 & 1,83 & 0,08 & 14,31 & 16,70 \\
\hline $\mathrm{CBC}$ & 2.238 .388 & 73.689 .237 & 1.468 .013 & 64.750 .678 & 30.321 .507 & 55.273 .102 & 158.376 & 3,04 & 2,27 & 0,55 & 0,24 & 0,24 \\
\hline CEON & 775.196 & 164.109 .261 & -7.891 .411 & 28.556 .970 & 27.370 .101 & 152.819 .945 & 74.935 .959 & 0,47 & $-27,63$ & 0,18 & 72,41 & 262,41 \\
\hline CGC & -61.787 .180 & 57.463 .997 & -67.032 .139 & -6.250 .349 & 18.857 .699 & 44.360 .648 & 0 & $-107,52$ & $1.072,45$ & 0,43 & 0 & 0 \\
\hline CMCM & 1.406 .576 & 276.653 .788 & 1.139 .891 & 262.717 .089 & 29.374 .755 & 263.863 .501 & 6.443 .536 & 0,51 & 0,43 & 0,11 & 2,39 & 2,45 \\
\hline $\mathrm{CMF}$ & 4.656 .981 & 83.427 .743 & 923.006 & 31.673 .038 & 142.154 .245 & 29.205 .292 & 0 & 5,58 & 2,91 & 4,87 & 0 & 0 \\
\hline CMP & 27.158 .629 & 493.965 .989 & 17.369 .837 & 292.562 .890 & 475.420 .370 & 329.181 .211 & 76.947 .904 & 5,50 & 5,94 & 1,44 & 20,82 & 26,30 \\
\hline CNTE & 2.543 .951 & 11.784 .618 & 2.285 .540 & 10.353 .981 & 18.644 .924 & 3.529 .881 & 14.849 & 21,59 & 22,07 & 5,28 & 0,14 & 0,14 \\
\hline COMI & 539.204 & 188.987 .421 & 850.645 & 133.194 .377 & 113.716 .459 & 105.092 .659 & 12.546 .041 & 0,29 & 0,64 & 1,08 & 8,61 & 9,42 \\
\hline $\mathrm{COS}$ & -117.182 .073 & 499.900 .018 & -133.495 .504 & -92.021 .529 & \begin{tabular}{|l|}
1.099 .750 .708 \\
\end{tabular} & 203.225 .976 & 990.135 & $-23,44$ & 145,07 & 5,41 & $-1,09$ & $-1,08$ \\
\hline COTE & 26.763 .130 & 630.665 .072 & 28.558 .866 & 540.817 .576 & 341.768 .185 & 380.165 .258 & 0 & 4,24 & 5,28 & 0,90 & 0 & 0 \\
\hline COTR & 1.957 .900 & 182.656 .543 & 1.085 .936 & 129.964 .290 & 43.255 .975 & 145.519 .689 & 30.302 .669 & 1,07 & 0,84 & 0,30 & 18,91 & 23,32 \\
\hline DAFR & 14.373 .944 & 438.727 .700 & 2.008 .175 & 157.590 .102 & 161.599 .658 & 299.794 .782 & 167.042 .255 & 3,28 & 1,27 & 0,54 & 51,46 & 106,00 \\
\hline ECT & -624.283 & 14.777 .197 & -596.485 & 11.698 .064 & 6.817 .985 & 7.104 .844 & 0 & $-4,22$ & $-5,10$ & 0,96 & 0 & 0 \\
\hline EFO & 649.181 & 251.691 .068 & 172.844 & 232.964 .488 & 26.430 .368 & 230.196 .175 & 1.137 .324 & 0,26 & 0,07 & 0,11 & 0,49 & 0,49 \\
\hline
\end{tabular}




\begin{tabular}{|c|c|c|c|c|c|c|c|c|c|c|c|c|}
\hline ELGS & 8.996 .684 & 46.396 .208 & 7.310 .566 & 26.260 .086 & 125.615 .939 & 8.699 .482 & 0 & 19,39 & 27,84 & 14,44 & 0 & 0 \\
\hline ELJ & -1.296 .420 & 29.639 .064 & -3.778 .037 & 25.631 .133 & 18.891 .831 & 11.733 .505 & 868.085 & $-4,37$ & $-14,74$ & 1,61 & 3,28 & 3,39 \\
\hline ELMA & 16.420 .386 & 323.373 .668 & 15.075 .281 & 269.148 .045 & 495.195 .622 & 233.495 .625 & 1.558 .086 & 5,08 & 5,60 & 2,12 & 0,58 & 0,58 \\
\hline ENP & 1.385 .721 & 31.722 .305 & 56.773 & 9.936 .674 & 17.837 .293 & 5.425 .826 & 3.507 .294 & 4,37 & 0,57 & 3,29 & 26,09 & 35,30 \\
\hline EPT & -27.105 .019 & 432.419 .499 & -48.063 .969 & 20.898 .016 & 199.082 .319 & 304.404 .885 & 278.383 .786 & $-6,27$ & $-229,99$ & 0,65 & 93,02 & $1.332,11$ \\
\hline IMP & -16.608 .101 & 408.352 .467 & -22.261 .046 & 296.828 .111 & 13.540 .400 & 90.810 .963 & 64.696 .047 & $-4,07$ & $-7,50$ & 0,15 & 17,90 & 21,80 \\
\hline MECF & 8.365 .602 & 48.492 .503 & 7.246 .828 & 42.913 .158 & 31.578 .535 & 24.743 .718 & 0 & 17,25 & 16,89 & 1,28 & 0 & 0 \\
\hline MEF & 187.971 & 40.665 .360 & 11.263 & 34.928 .783 & 17.664 .283 & 15.674 .226 & 1.506 .630 & 0,46 & 0,03 & 1,13 & 4,14 & 4,31 \\
\hline MJM & -4.051 .537 & 33.830 .932 & -4.872 .415 & -8.607 .446 & 35.742 .014 & 22.657 .811 & 0 & $-11,98$ & 56,61 & 1,58 & 0 & 0 \\
\hline OIL & 1.835 .912 & 378.359 .615 & 545.419 & 345.226 .806 & 115.773 .802 & 361.881 .727 & 4.263 .066 & 0,49 & 0,16 & 0,32 & 1,22 & 1,23 \\
\hline OLT & -158.895 .924 & 2.198 .423 .759 & -278.342 .623 & -826.884 .427 & 1.533 .016 .194 & 1.876 .114 .299 & 986.004 .655 & $-7,23$ & 33,66 & 0,82 & 619,66 & $-119,24$ \\
\hline PEI & 2.633 .974 & 68.847 .745 & 235.341 & 13.013 .030 & 521.232 .193 & 10.971 .825 & 22.910 .779 & 3,83 & 1,81 & 47,51 & 63,78 & 176,06 \\
\hline PPL & 1.109 .843 & 50.362 .569 & 2.929 .971 & 47.572 .517 & 53.828 .304 & 9.285 .759 & 0 & 2,20 & 6,16 & 5,80 & 0 & 0 \\
\hline PREH & 3.143 .303 & 262.126 .063 & 917.740 & 202.531 .399 & 64.764 .491 & 198.191 .648 & 25.605 .300 & 1,20 & 0,45 & 0,33 & 11,22 & 12,64 \\
\hline PTR & 15.595 .526 & 143.029 .244 & 15.813 .330 & 128.436 .335 & 95.488 .935 & 60.340 .022 & 0 & 10,90 & 12,31 & 1,58 & 0 & 0 \\
\hline RMAH & 5.568 .914 & 162.942 .722 & 4.077 .449 & 39.835 .319 & 203.467 .822 & 36.303 .710 & 537.635 & 3,42 & 10,24 & 5,60 & 1,33 & 1,35 \\
\hline ROCE & 5.683 .105 & 234.855 .956 & 2.712 .128 & 133.187 .047 & 107.017 .783 & 195.268 .211 & 27.393 .645 & 2,42 & 2,04 & 0,55 & 17,06 & 20,57 \\
\hline $\mathrm{RPH}$ & 12.896 .086 & 388.347 .032 & 10.687 .756 & 91.212 .485 & 385.169 .835 & 70.021 .302 & 5.061 .758 & 3,32 & 11,72 & 5,50 & 5,26 & 5,55 \\
\hline RRC & \begin{tabular}{|l|}
-274.099 .425 \\
\end{tabular} & 6.563 .566 .885 & -735.847 .584 & -134.091 .000 & 10.174 .808 .952 & 4.300 .764 .385 & 0 & $-4,18$ & 548,77 & 2,37 & 0 & 0 \\
\hline RTRA & 3.029 .782 & 47.863 .063 & 1.188 .188 & 23.037 .153 & 41.308 .854 & 21.786 .116 & 1.404 .554 & 6,33 & 5,16 & 1,90 & 5,75 & 6,10 \\
\hline SCD & 38.020 .442 & 347.755 .737 & 33.857 .309 & 256.395 .838 & 235.648 .166 & 85.823 .334 & 0 & 10,93 & 13,21 & 2,75 & 0 & 0 \\
\hline SNO & 155.507 & 96.507 .307 & 380.016 & 88.410 .039 & 55.795 .808 & 41.518 .154 & 0 & 0,16 & 0,43 & 1,34 & 0 & 0 \\
\hline SNP & 5.033.585.274 & 33.819 .553 .700 & 3.685 .607 .226 & 18.890 .892 .162 & 16.565 .465 .973 & 28.568 .337 .614 & 2.255 .228 .600 & 14,88 & 19,51 & 0,58 & 10,66 & 11,94 \\
\hline SOCP & 6.776 .617 & 106.795 .772 & 7.092 .137 & 99.800 .086 & 59.103 .455 & 56.451 .421 & 2.299 .916 & 6,35 & 7,11 & 1,05 & 2,25 & 2,30 \\
\hline SPCU & 2.488 .227 & 158.590 .729 & 1.177 .362 & 128.786 .567 & 148.719 .552 & 123.780 .263 & 11.047 .413 & 1,57 & 0,91 & 1,20 & 7,90 & 8,58 \\
\hline SRT & -467.884 & 31.241 .446 & -823.2 & 13.152 .686 & 9.338 .719 & 14.159 .841 & 5.035 .956 & $-1,50$ & $-0,006$ & 0,66 & 27,69 & 38,29 \\
\hline STIB & 26.303 .030 & 380.864 .669 & 19.462 .703 & 260.042 .571 & 207.570 .716 & 227.785 .195 & 7.199 .501 & 6,91 & 7,48 & 0,91 & 2,69 & 2,77 \\
\hline STZ & -1.479 .491 & 179.125 .518 & -1.330 .486 & 167.543 .309 & 14.232 .173 & 171.044 .907 & 4.967 .730 & $-0,83$ & $-0,79$ & 0,08 & 2,88 & 2,97 \\
\hline TBM & -12.455 .884 & 161.531 .440 & -19.411 .417 & 67.520 .493 & 46.491 .763 & 121.135 .007 & 23.500 .980 & $-7,71$ & $-28,75$ & 0,38 & 25,82 & 34,81 \\
\hline TEL & 159.473 .510 & 5.215 .805 .828 & 90.913 .316 & 2.468 .483 .557 & 3.113 .142 .778 & 3.667 .984 .393 & 943.492 .527 & 3,06 & 3,68 & 0,85 & 27,65 & 38,22 \\
\hline TGN & 442.570 .859 & 4.089 .037 .220 & 379.571 .465 & 3.262 .877 .964 & 1.343 .321 .806 & 3.402 .786 .965 & 75.147 .643 & 10,82 & 11,63 & 0,39 & 2,25 & 2,30 \\
\hline TRP & -11.234 .148 & 236.656 .907 & -14.642 .198 & 130.073 .871 & 209.359 .979 & 156.800 .070 & 35.999 .810 & $-4,75$ & $-11,26$ & 1,34 & 21,68 & 27,68 \\
\hline TUFE & 9.111 .498 & 194.142 .239 & 6.738 .894 & 173.052 .703 & 48.437 .997 & 178.306 .529 & 17.119 .011 & 4,69 & 3,89 & 0,27 & 9,00 & 9,89 \\
\hline UAM & 3.406 .949 & 96.850 .931 & 542.995 & 46.546 .752 & 84.091 .931 & 50.656 .972 & 7.310 .786 & 3,52 & 1,17 & 1,66 & 13,57 & 15,71 \\
\hline VESY & -3.914 .487 & 43.362 .218 & -4.879 .702 & 18.597 .132 & 35.986 .329 & 20.263 .039 & 153.352 & $-9,03$ & $-26,24$ & 1,78 & 0,82 & 0,82 \\
\hline VNC & 5.908 .103 & 224.686 .235 & 1.997 .353 & 88.234 .850 & 163.751 .672 & 161.444 .013 & 62.321 .559 & 2,63 & 2,26 & 1,01 & 41,39 & 70,63 \\
\hline
\end{tabular}

Source: www.bvb.ro, Authors' processing 
Annex no. 2

Determining financial variables needed for financial diagnosis (2)

\begin{tabular}{|c|c|c|c|c|c|c|c|c|c|c|c|c|}
\hline $\begin{array}{c}\text { Company } \\
\text { name } \\
\text { (transaction } \\
\text { symbol) }\end{array}$ & $\begin{array}{l}\text { Ability to } \\
\text { finance } \\
\text { itself }\end{array}$ & $\begin{array}{c}\text { Current } \\
\text { assets + } \\
\text { Prepaid } \\
\text { expenses }\end{array}$ & Inventories & $\begin{array}{l}\text { Current } \\
\text { liabilities }\end{array}$ & $\begin{array}{c}\text { Debts: The } \\
\text { amounts to } \\
\text { be paid } \\
\text { within a } \\
\text { period of } \\
\text { less than } \\
\text { one year }\end{array}$ & $\begin{array}{c}\text { Cash and } \\
\text { banks }\end{array}$ & $\begin{array}{c}\text { Correlation } \\
\text { between } \\
\text { term debt } \\
\text { and ability } \\
\text { of self- } \\
\text { financing }\end{array}$ & $\begin{array}{c}\text { Liquidity } \\
\text { asset }\end{array}$ & $\begin{array}{c}\text { Rotational } \\
\text { speed of } \\
\text { current } \\
\text { assets }\end{array}$ & $\begin{array}{l}\text { Reduced } \\
\text { liquidity }\end{array}$ & $\begin{array}{c}\text { Patrim } \\
\text { onial } \\
\text { solvenc } \\
y\end{array}$ & $\begin{array}{c}\text { Immed } \\
\text { iate } \\
\text { liquidit } \\
y\end{array}$ \\
\hline & & & & & & & \multicolumn{2}{|c|}{ coeff. } & days & coeff. & $\%$ & coeff. \\
\hline ALR & 325.158 .383 & 931.837 .290 & 447.520 .845 & 245.819 .828 & 237.136 .574 & 254.511 .559 & 1,76 & 3,79 & $1.046,02$ & 1,97 & 63,97 & 1,07 \\
\hline ALT & 4.275 .414 & 590.755 .202 & 20.546 .081 & 64.800 .322 & 56.963 .602 & 376.896 & 0,61 & 9,12 & $50.433,86$ & 8,80 & 61,75 & 0,01 \\
\hline ALU & 8.626 .646 & 61.662 .978 & 14.592 .025 & 15.821 .444 & 15.761 .595 & 19.109 .137 & 0 & 3,90 & $2.609,01$ & 2,98 & 80,90 & 1,21 \\
\hline AMO & -20.874 .035 & 32.751 .343 & 12.078 .850 & 19.772 .384 & 19.772 .384 & 19.052 & 0 & 1,66 & $-572,68$ & 1,05 & 72,78 & 0,00 \\
\hline APC & 10.445 .984 & 54.037 .475 & 20.506 .976 & 18.260 .393 & 18.181 .627 & 18.127 .800 & 0 & 2,96 & $1.888,16$ & 1,84 & 76,39 & 1,00 \\
\hline ARM & -1.452 .140 & 13.633 .976 & 12.078 .850 & 6.246 .013 & 5.991 .786 & 228.389 & $-14,87$ & 2,18 & $-3.426,94$ & 0,25 & 0,62 & 0,04 \\
\hline ARS & 34.147 .442 & 85.100 .086 & 15.474 .466 & 21.792 .580 & 18.119 .220 & 439.799 & 0 & 3,91 & 909,63 & 3,19 & 63,87 & 0,02 \\
\hline ART & 96.520 .776 & 427.981 .211 & 215.065 .774 & 164.111 .746 & 164.070 .044 & 9.535 .257 & 3,15 & 2,61 & $1.618,44$ & 1,30 & 47,57 & 0,06 \\
\hline ARTE & 10.227 .783 & 89.792 .940 & 48.218 .297 & 72.795 .812 & 68.937 .111 & 3.539 .505 & 0 & 1,23 & $3.204,45$ & 0,57 & 52,00 & 0,05 \\
\hline ATB & 45.548 .341 & 273.949 .313 & 41.932 .333 & 147.660 .127 & 142.722 .089 & 5.339 .857 & 0 & 1,86 & $2.195,28$ & 1,57 & 63,89 & 0,04 \\
\hline $\mathrm{BCM}$ & 1.477 .201 & 14.260 .861 & 180.829 & 492.398 & 492.398 & 2.234 .049 & 0 & 28,96 & $3.523,70$ & 28,59 & 98,58 & 4,54 \\
\hline $\mathrm{BIO}$ & 19.777 .031 & 116.257 .902 & 15.231 .010 & 26.547 .462 & 26.547 .462 & 736.337 & 0,02 & 4,38 & $2.145,63$ & 3,81 & 83,26 & 0,03 \\
\hline BRM & 3.428 .963 & 13.284 .196 & 11.655 .151 & 6.259 .537 & 6.259 .537 & 29.847 & 0 & 2,12 & $1.414,05$ & 0,26 & 78,65 & 0,00 \\
\hline CAOR & 1.763 .139 & 11.783 .174 & 131.627 & 8.797 .100 & 8.619 .700 & 9.606 .415 & 6,47 & 1,34 & $2.439,32$ & 1,32 & 75,23 & 1,11 \\
\hline $\mathrm{CBC}$ & 3.139 .195 & 18.416 .135 & 10.266 .594 & 8.779 .072 & 8.774 .901 & 362.388 & 0,05 & 2,10 & $2.141,28$ & 0,93 & 87,87 & 0,04 \\
\hline CEON & -874.140 & 11.289 .316 & 7.610 .260 & 55.375 .589 & 53.838 .543 & 1.631 .892 & $-85,73$ & 0,20 & $-4.713,89$ & 0,07 & 17,40 & 0,03 \\
\hline CGC & -17.877 .314 & 13.103 .349 & 8.663 .546 & 63.623 .314 & 63.623 .314 & 371.813 & 0 & 0,21 & $-267,53$ & 0,07 & $-10,88$ & 0,01 \\
\hline CMCM & 6.127 .250 & 12.790 .287 & 1.376 .300 & 7.493 .163 & 6.945 .341 & 1.482 .873 & 1,05 & 1,71 & 761,92 & 1,52 & 94,96 & 0,21 \\
\hline $\mathrm{CMF}$ & 7.276 .638 & 54.222 .451 & 22.996 .245 & 50.963 .383 & 50.215 .466 & 4.061 .680 & 0 & 1,06 & $2.719,83$ & 0,61 & 37,96 & 0,08 \\
\hline CMP & 53.759 .411 & 164.784 .778 & 55.605 .002 & 123.195 .195 & 99.869 .085 & 3.488 .210 & 1,43 & 1,34 & $1.118,81$ & 0,89 & 59,23 & 0,03 \\
\hline CNTE & 2.865 .135 & 8.254 .737 & 1.894 .090 & 1.415 .788 & 1.415 .788 & 4.369 .684 & 0,01 & 5,83 & $1.051,60$ & 4,49 & 87,86 & 3,09 \\
\hline COMI & 9.359 .657 & 83.894 .762 & 14.780 .100 & 42.147 .476 & 42.147 .476 & 15.031 .391 & 1,34 & 1,99 & $3.271,66$ & 1,64 & 70,48 & 0,36 \\
\hline COS & -118.679 .304 & 296.674 .042 & 160.842 .006 & 589.348 .406 & 589.348 .406 & 41.317 .864 & $-0,01$ & 0,50 & $-912,43$ & 0,23 & $-18,41$ & 0,07 \\
\hline COTE & 89.776 .573 & 250.499 .814 & 19.509 .879 & 67.904 .538 & 67.904 .538 & 1.328 .900 & 0 & 3,69 & $1.018,44$ & 3,40 & 85,75 & 0,02 \\
\hline COTR & 7.543 .070 & 37.136 .854 & 26.836 .115 & 20.628 .933 & 20.337 .347 & 4.374 .801 & 4,02 & 1,80 & $1.797,01$ & 0,50 & 71,15 & 0,22 \\
\hline DAFR & 16.128 .980 & 138.932 .918 & 51.454 .914 & 113.120 .356 & 113.120 .356 & 4.374 .801 & 10,36 & 1,23 & $3.144,06$ & 0,77 & 35,92 & 0,04 \\
\hline ECT & -322.932 & 7.672 .353 & 2.778 .599 & 3.079 .133 & 3.059 .113 & 644.376 & 0 & 2,49 & $-8.671,82$ & 1,59 & 79,16 & 0,21 \\
\hline
\end{tabular}




\begin{tabular}{|c|c|c|c|c|c|c|c|c|c|c|c|c|}
\hline EFO & 7.940 .001 & 21.494 .893 & 2.708 .150 & 17.589 .256 & 15.716 .221 & 7.934 .697 & 0,14 & 1,22 & 988,12 & 1,07 & 92,56 & 0,50 \\
\hline ELGS & 8.140 .645 & 37.696 .726 & 17.691 .551 & 20.136 .122 & 19.975 .509 & 3.720 .512 & 0 & 1,87 & $1.690,20$ & 0,99 & 56,60 & 0,19 \\
\hline ELJ & -3.987 .223 & 17.905 .559 & 10.350 .588 & 2.794 .715 & 2.760 .116 & 1.942 .714 & $-0,22$ & 6,41 & $-1.639,12$ & 2,70 & 86,48 & 0,70 \\
\hline ELMA & 20.816 .726 & 89.878 .043 & 21.518 .630 & 51.866 .006 & 45.825 .385 & 12.302 .452 & 0,07 & 1,73 & $1.575,92$ & 1,32 & 83,23 & 0,27 \\
\hline ENP & 444.401 & 26.296 .479 & 7.715 .933 & 17.831 .316 & 17.831 .316 & 158.227 & 7,89 & 1,47 & $21.598,09$ & 1,04 & 31,32 & 0,01 \\
\hline EPT & -41.229 .967 & 128.014 .614 & 18.464 .606 & 127.323 .860 & 127.240 .953 & 5.208 .461 & $-6,75$ & 1,01 & $-1.133,29$ & 0,86 & 4,83 & 0,04 \\
\hline IMP & -15.055 .151 & 317.541 .504 & 258.299 .960 & 44.418 .653 & 40.564 .811 & 8.915 .228 & $-4,30$ & 7,15 & $-7.698,54$ & 1,33 & 72,69 & 0,22 \\
\hline MECF & 8.528 .663 & 25.426 .598 & 7.747.394 & 6.981 .407 & 6.877 .370 & 10.358 .837 & 0 & 3,64 & $1.088,18$ & 2,53 & 88,49 & 1,51 \\
\hline MEF & 994.713 & 24.991 .134 & 13.464 .910 & 4.229 .947 & 3.559 .147 & 6.197 .363 & 1,51 & 5,91 & $9.170,25$ & 2,72 & 85,89 & 1,74 \\
\hline MJM & -5.321 .528 & 11.173 .121 & 2.876 .496 & 42.438 .378 & 42.277 .382 & 1.229 .957 & 0 & 0,26 & $-766,36$ & 0,20 & $-25,44$ & 0,03 \\
\hline OIL & 15.894 .222 & 16.477 .888 & 2.876 .496 & 26.578.205 & 26.025 .160 & 1.066 .463 & 0,27 & 0,62 & 378,40 & 0,51 & 91,24 & 0,04 \\
\hline OLT & -149.700 .775 & 322.309 .460 & 101.313 .664 & 2.009 .452 .066 & 1.553 .448 .319 & 3.326 .508 & $-6,59$ & 0,16 & $-785,85$ & 0,11 & $-37,61$ & 0 \\
\hline PEI & 871.380 & 57.875 .920 & 52.918 .968 & 26.921 .671 & 26.917 .309 & 1.506 .155 & 26,29 & 2,15 & $24.242,82$ & 0,18 & 18,90 & 0,06 \\
\hline PPL & 3.753 .950 & 41.076 .810 & 4.992 .598 & 2.790 .052 & 2.790 .052 & 1.033 .561 & 0 & 14,72 & $3.993,94$ & 12,93 & 94,46 & 0,37 \\
\hline PREH & 6.869 .810 & 63.934 .415 & 12.381 .839 & 33.989 .364 & 33.863 .201 & 14.699 .915 & 3,73 & 1,88 & $3.396,90$ & 1,52 & 77,26 & 0,43 \\
\hline PTR & 25.057 .951 & 82.689 .222 & 5.822 .873 & 11.738 .025 & 11.607 .647 & 16.709 .881 & 0 & 7,04 & $1.204,47$ & 6,55 & 89,80 & 1,44 \\
\hline RMAH & 8.542 .880 & 126.639 .012 & 24.358 .494 & 120.614 .152 & 120.614 .152 & 15.082 .162 & 0,06 & 1,05 & $5.410,73$ & 0,85 & 24,45 & 0,13 \\
\hline ROCE & 6.160 .393 & 39.587 .745 & 11.017 .892 & 74.275 .264 & 68.709 .356 & 8.672 .653 & 4,45 & 0,53 & $2.345,55$ & 0,38 & 56,71 & 0,13 \\
\hline $\mathrm{RPH}$ & 16.046 .435 & 318.325 .730 & 44.273 .210 & 292.018 .475 & 291.992 .463 & 25.404 .405 & 0,32 & 1,09 & $7.240,79$ & 0,94 & 23,49 & 0,09 \\
\hline RRC & -484.821 .367 & 2.262 .802 .500 & 906.137 .452 & 6.617 .973 .868 & 6.617 .973 .868 & 43.062 .148 & 0 & 0,34 & $-1.703,56$ & 0,20 & $-2,04$ & 0,01 \\
\hline RTRA & 2.257 .301 & 26.076 .947 & 9.873 .752 & 23.421 .356 & 23.416 .657 & 280.157 & 0,62 & 1,11 & $4.216,58$ & 0,69 & 48,13 & 0,01 \\
\hline SCD & 41.393 .793 & 261.932 .403 & 25.474 .665 & 78.500 .876 & 78.422 .152 & 10.227 .387 & 0 & 3,34 & $2.309,65$ & 3,01 & 73,73 & 0,13 \\
\hline SNO & 5.329 .027 & 54.989 .153 & 32.684 .422 & 7.767 .081 & 7.767 .081 & 1.743 .302 & 0 & 7,08 & $3.766,36$ & 2,87 & 91,61 & 0,22 \\
\hline SNP & 5.782 .794 .691 & 5.251 .216 .086 & 1.695 .805 .503 & 4.710 .750 .374 & 4.677 .942 .732 & 567.026 .496 & 0,39 & 1,11 & 331,45 & 0,75 & 55,86 & 0,12 \\
\hline SOCP & 12.831 .304 & 50.344 .351 & 1.518 .066 & 3.955 .210 & 3.771 .610 & 2.673 .494 & 0,18 & 12,73 & $1.432,10$ & 12,34 & 93,45 & 0,71 \\
\hline SPCU & 7.213 .309 & 34.810 .466 & 10.809 .772 & 18.756 .749 & 18.648 .416 & 5.695 .384 & 1,53 & 1,86 & $1.761,44$ & 1,28 & 81,21 & 0,31 \\
\hline SRT & -256.885 & 17.081 .605 & 3.442 .061 & 13.052 .804 & 12.813 .608 & 881.031 & $-19,60$ & 1,31 & $-24.270,73$ & 1,04 & 42,10 & 0,07 \\
\hline STIB & 36.465 .478 & 153.079 .474 & 46.457 .765 & 112.055 .012 & 111.897 .337 & 2.535 .990 & 0,20 & 1,37 & $1.532,24$ & 0,95 & 68,28 & 0,02 \\
\hline STZ & -687.624 & 8.080 .611 & 3.081 .180 & 6.614 .479 & 6.263 .673 & 605.733 & $-7,22$ & 1,22 & $-4.289,30$ & 0,76 & 93,53 & 0,10 \\
\hline TBM & -12.700 .531 & 40.396 .433 & 31.462 .798 & 67.714 .785 & 66.562 .407 & 1.463 .811 & $-1,85$ & 0,60 & $-1.160,95$ & 0,13 & 41,80 & 0,02 \\
\hline TEL & 445.497 .407 & 1.547 .821 .435 & 41.723 .456 & 1.755 .883 .953 & 1.390 .691 .247 & 178.684 .658 & 2,12 & 0,88 & $1.268,14$ & 0,86 & 47,33 & 0,13 \\
\hline TGN & 541.699 .296 & 686.250 .255 & 43.247 .769 & 708.584 .237 & 358.127 .194 & 19.154 .501 & 0,14 & 0,97 & 462,40 & 0,91 & 79,80 & 0,05 \\
\hline TRP & 5.434 .449 & 79.856 .837 & 30.013 .441 & 66.806 .132 & 66.806 .132 & 2.501 .319 & 6,62 & 1,20 & $5.363,51$ & 0,75 & 54,96 & 0,04 \\
\hline TUFE & 11.371 .011 & 15.835 .710 & 909.212 & 3.931 .462 & 3.740 .372 & 13.222 .585 & 1,51 & 4,03 & 508,31 & 3,80 & 89,14 & 3,54 \\
\hline UAM & 6.156 .840 & 46.193 .959 & 22.968 .122 & 42.993 .393 & 42.857 .050 & 1.787 .067 & 1,19 & 1,07 & $2.738,55$ & 0,54 & 48,06 & 0,04 \\
\hline VESY & -621.146 & 23.099 .179 & 9.717 .323 & 24.611 .734 & 24.580 .567 & 1.157 .131 & $-0,25$ & 0,94 & $-13.573,62$ & 0,54 & 42,89 & 0,05 \\
\hline VNC & 9.559 .504 & 63.242 .222 & 22.546 .777 & 74.129 .826 & 63.144 .123 & 870.784 & 6,52 & 0,85 & $2.414,71$ & 0,55 & 39,27 & 0,01 \\
\hline
\end{tabular}

Source: www.bvb.ro, Authors' processing 
Annex no. 3

Setting the scoring and determining the aggregate mark

\begin{tabular}{|c|c|c|c|c|c|c|c|c|c|c|c|c|}
\hline $\begin{array}{c}\text { Company } \\
\text { name } \\
\text { (transaction } \\
\text { symbol) }\end{array}$ & $\begin{array}{c}\text { Economic } \\
\text { profitability }\end{array}$ & $\begin{array}{l}\text { Return on } \\
\text { equity }\end{array}$ & $\begin{array}{c}\text { The } \\
\text { productivity } \\
\text { of invested } \\
\text { capital }\end{array}$ & $\begin{array}{c}\text { Indebtedness } \\
\text { rate }\end{array}$ & $\begin{array}{l}\text { Financial } \\
\text { Leverage }\end{array}$ & $\begin{array}{l}\text { Correlation } \\
\text { between } \\
\text { term debt } \\
\text { and ability } \\
\text { of self- } \\
\text { financing }\end{array}$ & $\begin{array}{l}\text { Liquidity } \\
\text { asset }\end{array}$ & $\begin{array}{l}\text { Rotational } \\
\text { speed of } \\
\text { current } \\
\text { assets }\end{array}$ & $\begin{array}{l}\text { Reduced } \\
\text { liquidity }\end{array}$ & $\begin{array}{c}\text { Patrimonial } \\
\text { solvency }\end{array}$ & $\begin{array}{l}\text { Immediate } \\
\text { liquidity }\end{array}$ & $\begin{array}{c}\text { Aggregate } \\
\text { score }\end{array}$ \\
\hline $\begin{array}{c}\text { Coefficient of } \\
\text { importance }\end{array}$ & 2 & 5 & 1 & 5 & 2 & 5 & 1 & 1 & 5 & 1 & 5 & \\
\hline ALR & 80 & 80 & 20 & 20 & 100 & 100 & 100 & 20 & 100 & 60 & 100 & 77,58 \\
\hline ALT & 20 & 20 & 20 & 20 & 100 & 100 & 100 & 20 & 100 & 60 & 20 & 52,73 \\
\hline ALU & 40 & 60 & 60 & 100 & 100 & 100 & 100 & 20 & 100 & 80 & 100 & 383,03 \\
\hline AMO & 20 & 20 & 20 & 100 & 100 & 100 & 100 & 100 & 40 & 60 & 20 & 58,18 \\
\hline APC & 60 & 80 & 60 & 100 & 100 & 100 & 100 & 20 & 100 & 80 & 80 & 87,27 \\
\hline ARM & 20 & 20 & 20 & 20 & 20 & 100 & 100 & 100 & 20 & 20 & 20 & 36,97 \\
\hline ARS & 40 & 80 & 40 & 100 & 100 & 100 & 100 & 20 & 100 & 60 & 20 & 75,76 \\
\hline ART & 40 & 100 & 20 & 20 & 100 & 100 & 100 & 20 & 60 & 40 & 20 & 59,39 \\
\hline ARTE & 40 & 60 & 60 & 100 & 100 & 100 & 20 & 20 & 20 & 40 & 20 & 58,18 \\
\hline ATB & 40 & 60 & 20 & 100 & 100 & 100 & 100 & 20 & 80 & 60 & 20 & 69,09 \\
\hline BCM & 20 & 20 & 20 & 100 & 100 & 100 & 100 & 20 & 100 & 80 & 100 & 77,58 \\
\hline $\mathrm{BIO}$ & 40 & 60 & 20 & 80 & 100 & 100 & 100 & 20 & 100 & 80 & 20 & 69,70 \\
\hline BRM & 40 & 60 & 20 & 100 & 100 & 100 & 100 & 20 & 20 & 80 & 20 & 60,61 \\
\hline CAOR & 20 & 20 & 20 & 20 & 100 & 60 & 40 & 20 & 60 & 80 & 100 & 51,52 \\
\hline $\mathrm{CBC}$ & 20 & 40 & 20 & 80 & 100 & 100 & 100 & 20 & 20 & 80 & 20 & 53,33 \\
\hline CEON & 20 & 20 & 20 & 20 & 20 & 100 & 20 & 100 & 20 & 20 & 20 & 34,55 \\
\hline CGC & 20 & 100 & 20 & 100 & 100 & 100 & 20 & 100 & 20 & 20 & 20 & 63,64 \\
\hline CMCM & 20 & 20 & 20 & 20 & 100 & 100 & 100 & 20 & 80 & 80 & 20 & 50,30 \\
\hline CMF & 40 & 40 & 80 & 100 & 100 & 100 & 20 & 20 & 20 & 40 & 20 & 55,76 \\
\hline CMP & 40 & 60 & 20 & 20 & 100 & 100 & 40 & 20 & 20 & 60 & 20 & 46,06 \\
\hline CNTE & 100 & 100 & 100 & 100 & 100 & 100 & 100 & 20 & 100 & 80 & 100 & 96,97 \\
\hline COMI & 20 & 20 & 20 & 20 & 100 & 100 & 100 & 20 & 100 & 60 & 40 & 55,76 \\
\hline COS & 20 & 100 & 100 & 100 & 100 & 100 & 20 & 100 & 20 & 20 & 20 & 66,06 \\
\hline COTE & 40 & 60 & 20 & 100 & 100 & 100 & 100 & 20 & 100 & 80 & 20 & 72,73 \\
\hline COTR & 20 & 20 & 20 & 20 & 100 & 80 & 100 & 20 & 20 & 60 & 20 & 37,58 \\
\hline DAFR & 20 & 20 & 20 & 20 & 80 & 20 & 20 & 20 & 20 & 40 & 20 & 24,24 \\
\hline
\end{tabular}




\begin{tabular}{|c|c|c|c|c|c|c|c|c|c|c|c|c|}
\hline ECT & 20 & 20 & 20 & 100 & 100 & 100 & 100 & 100 & 80 & 60 & 20 & 64,24 \\
\hline EFO & 20 & 20 & 20 & 60 & 100 & 100 & 20 & 20 & 40 & 80 & 40 & 50,91 \\
\hline ELGS & 80 & 100 & 100 & 100 & 100 & 100 & 100 & 20 & 20 & 60 & 20 & 70,91 \\
\hline ELJ & 20 & 20 & 20 & 20 & 100 & 100 & 100 & 100 & 100 & 80 & 60 & 61,82 \\
\hline ELMA & 40 & 60 & 40 & 60 & 100 & 100 & 100 & 20 & 60 & 80 & 40 & 64,24 \\
\hline ENP & 40 & 20 & 60 & 20 & 100 & 60 & 40 & 20 & 20 & 40 & 20 & 34,55 \\
\hline EPT & 20 & 20 & 20 & 20 & 20 & 100 & 20 & 100 & 20 & 20 & 20 & 34,55 \\
\hline IMP & 20 & 20 & 20 & 20 & 100 & 100 & 100 & 100 & 60 & 60 & 20 & 49,09 \\
\hline MECF & 80 & 100 & 20 & 100 & 100 & 100 & 100 & 20 & 100 & 80 & 100 & 93,33 \\
\hline MEF & 20 & 20 & 20 & 20 & 100 & 100 & 100 & 20 & 100 & 80 & 100 & 65,45 \\
\hline MJM & 20 & 100 & 20 & 100 & 100 & 100 & 20 & 100 & 20 & 20 & 20 & 63,64 \\
\hline OIL & 20 & 20 & 20 & 20 & 100 & 100 & 20 & 20 & 20 & 80 & 20 & 38,79 \\
\hline OLT & 20 & 100 & 20 & 20 & 100 & 100 & 20 & 100 & 20 & 20 & 20 & 51,52 \\
\hline PEI & 20 & 20 & 100 & 20 & 20 & 20 & 100 & 20 & 20 & 20 & 20 & 24,85 \\
\hline PPL & 20 & 60 & 100 & 100 & 100 & 100 & 100 & 20 & 100 & 80 & 40 & 76,97 \\
\hline PREH & 20 & 20 & 20 & 20 & 100 & 100 & 100 & 20 & 80 & 80 & 40 & 53,33 \\
\hline PTR & 60 & 80 & 20 & 100 & 100 & 100 & 100 & 20 & 100 & 80 & 100 & 89,09 \\
\hline RMAH & 20 & 80 & 100 & 20 & 100 & 100 & 20 & 20 & 20 & 20 & 20 & 48,48 \\
\hline ROCE & 20 & 40 & 20 & 20 & 100 & 80 & 20 & 20 & 20 & 60 & 20 & 38,18 \\
\hline RPH & 20 & 80 & 100 & 20 & 100 & 100 & 20 & 20 & 20 & 20 & 20 & 48,48 \\
\hline RRC & 20 & 100 & 60 & 100 & 100 & 100 & 20 & 100 & 20 & 20 & 20 & 64,85 \\
\hline RTRA & 40 & 60 & 20 & 20 & 100 & 100 & 20 & 20 & 20 & 40 & 20 & 44,85 \\
\hline SCD & 60 & 80 & 40 & 100 & 100 & 100 & 100 & 20 & 100 & 60 & 20 & 76,97 \\
\hline SNO & 20 & 20 & 20 & 100 & 100 & 100 & 100 & 20 & 100 & 80 & 20 & 65,45 \\
\hline SNP & 60 & 100 & 20 & 20 & 100 & 100 & 20 & 20 & 20 & 60 & 20 & 52,73 \\
\hline SOCP & 40 & 60 & 20 & 20 & 100 & 100 & 100 & 20 & 100 & 80 & 60 & 66,67 \\
\hline SPCU & 20 & 20 & 20 & 20 & 100 & 100 & 100 & 20 & 60 & 80 & 40 & 50,30 \\
\hline SRT & 20 & 20 & 20 & 20 & 100 & 100 & 40 & 100 & 40 & 40 & 20 & 43,64 \\
\hline STIB & 40 & 60 & 20 & 20 & 100 & 100 & 40 & 20 & 20 & 60 & 20 & 46,06 \\
\hline STZ & 20 & 20 & 20 & 20 & 100 & 100 & 20 & 100 & 20 & 80 & 20 & 41,21 \\
\hline TBM & 20 & 20 & 20 & 20 & 100 & 100 & 20 & 100 & 20 & 40 & 20 & 40,00 \\
\hline TEL & 20 & 40 & 20 & 20 & 100 & 100 & 20 & 20 & 20 & 40 & 20 & 40,61 \\
\hline TGN & 60 & 80 & 20 & 20 & 100 & 100 & 20 & 20 & 20 & 80 & 20 & 50,30 \\
\hline TRP & 20 & 20 & 20 & 20 & 100 & 60 & 20 & 20 & 20 & 60 & 20 & 32,12 \\
\hline TUFE & 40 & 40 & 20 & 20 & 100 & 100 & 100 & 20 & 100 & 80 & 100 & 69,70 \\
\hline UAM & 20 & 20 & 20 & 20 & 100 & 100 & 20 & 20 & 20 & 40 & 20 & 37,58 \\
\hline VESY & 20 & 20 & 20 & 20 & 100 & 100 & 20 & 100 & 20 & 40 & 20 & 40,00 \\
\hline VNC & 20 & 40 & 20 & 20 & 100 & 60 & 20 & 20 & 20 & 40 & 20 & 34,55 \\
\hline
\end{tabular}

